\title{
Associations of udder biometry with subclinical mastitis in Gir crossbred cows
}

\author{
AS Shinde ${ }^{1}$, MG Mote ${ }^{1}$, SU Bhoite ${ }^{2}$ and UY Bhoite ${ }^{1}$
}

Received: 12 November 2020 / Accepted: 21 January 2021 / Published online: 27 July 2021

(C) Indian Dairy Association (India) 2021

\begin{abstract}
The investigation was undertaken on $110 \mathrm{Gir}$ crossbred cows of different order of lactation and stage of lactation maintained at Research cum Development Project on Cattle, MPKV, Rahuri. The overall least squares means of udder length, udder width, udder depth and udder circumference were $65.23 \pm 1.45,63.24 \pm 1.45,19.03 \pm 0.51$ and $86.49 \pm 1.50 \mathrm{~cm}$ respectively. The least squares analysis of variance showed significant $(\mathrm{P}<0.05)$ effect due to order of lactation on udder length in crossbred cows. Also, order of lactation had significant $(\mathrm{P}<0.01)$ effect on udder width and udder circumference. However, stage of lactation exerted non-significant influence on all udder measurement traits. In crossbred cows, udder length had positive and significant $(\mathrm{P}<0.01)$ correlation with udder width, udder circumference and udder depth. The correlation of udder width with udder circumference and udder depth was positive and highly significant $(\mathrm{P}<0.01)$. There was positive and significant $(\mathrm{P}<0.01)$ correlation of udder circumference with udder depth. The frequencies of trough, round, goaty and pendulous type udder in crossbred cows were $63.64 \%, 8.18 \%, 11.82 \%$ and $16.36 \%$ respectively. Among 110 cows, 48 (43.64\%) cows were found positive for subclinical mastitis. The higher occurrence of subclinical mastitis was observed in cows having pendulous udder $(66.66 \%)$ followed by goaty $(53.84 \%)$, round $(44.44 \%)$ and trough $(35.71 \%)$ shape udder. Maximum number of positive subclinical mastitis cases were found in larger udder length $(>75$ $\mathrm{cm})$, udder width $(>75 \mathrm{~cm})$, udder depth $(>25 \mathrm{~cm})$ and udder circumference $(>95 \mathrm{~cm})$. Highest occurrence $(78.26 \%)$ of subclinical mastitis was found in cows of sixth and above lactation.
\end{abstract}

${ }^{1}$ Department of Animal Husbandry and Dairy Science, Mahatma Phule Krishi Vidyapeeth, Rahuri, District Ahmednagar (M.S.), 413722

${ }^{2}$ Department of IWM, Mahatma Phule Krishi Vidyapeeth, Rahuri, District Ahmednagar (M.S.), 413722.

MG Mote $(\square)$

RCDP on Cattle, Mahatma Phule Krishi Vidyapeeth,

Rahuri, District Ahmednagar 413 722, MS, India

Email:mahendramote18@gmail.com
Maximum occurrence of subclinical mastitis was noted in cows which were in late (46.15\%) stage of lactation followed by early $(40 \%)$ and mid (37\%) stage of lactation. The traits udder shape, udder length and udder depth had positive and significant association with incidence of subclinical mastitis in crossbred cows.

Keywords: Crossbred, Mastitis, Pendulous, Udder

\section{Introduction}

Mastitis is one of the most prevailing diseases of high yielding dairy animals. It has been recognized for more than a century, and still continues to be a major cause of economic loss. Mastitis is a complex disease resulting from the interaction of infectious agents and poor managemental practices in dairy animals. A dairy herd without mastitis is virtually impossible under modern intensive farming conditions. Subclinical mastitis (SCM) is more common than clinical mastitis, but often goes undetected and given less importance than clinical mastitis. Physical characteristics of udder and teats are important traits associated with incidence of subclinical mastitis (George et al. 2007). Udder is the first site judgment of local brokers or animal husbandry men in our country for judging the milking ability of animals. Therefore, it is more important to have knowledge of morphology of udder and teats and its relation with the mastitis within this subclinical mastitis. Mastitis is an economically important disease of high yielding crossbred cows. It can occur in clinical and subclinical form. Clinical mastitis is readily apparent and easily detected by abnormalities in milk or the udder or the occurrence of secondary clinical signs. The prevalence of subclinical mastitis in dairy herds is often surprising to producers, moreover, subclinically infected udder quarters can develop clinical mastitis and the rate of new infections can be high (Zdunczyk et al. 2003). The invisible changes in subclinical mastitis can be recognized by California Mastitis Test (CMT). Hence the investigation was undertaken to record the udder measurements, categories various shapes of udder and estimate association of various udder traits with sub-clinical mastitis of crossbred cows. 


\section{Materials and Methods}

The observations for study were recorded for 110 Jersey X Gir halfbred (JG), HF X Gir halfbred (FG) and Phule Triveni (FJG) crossbred cows maintained at Research cum Development Project on Cattle, Mahatma Phule Krishi Vidyapeeth, Rahuri, District Ahmednagar (M.S.). The udder measurement traits were recorded on the basis of order of lactation and stage of lactation of crossbred cows. The observations of crossbred cows recorded were biometry of udder, shape of udder and status of subclinical mastitis. Udder length, width, depth and circumference were measured one to two hours before the evening milking after securing the animals properly in a standing position on a leveled pucca floor for the accuracy. All the measurements were recorded in centimeters. Shape of udder was determined through visual appraisal method adopted by Cerkascenko (1958) and accordingly categorized into different types, viz. trough, round, goaty and pendulous. California Mastitis Test developed by Pyorala (2003) was performed directly in the cowshed.

\section{Statistical analysis}

Statistical analysis of data was done by using standard procedures viz. mean, standard error, coefficient of variations, frequency distribution, analysis of variance and correlation coefficient. In order to overcome non-orthogonality of data resulting from unequal and disproportionate subclass frequencies, the least squares method as suggested by Harvey (1990) was used for analysis. Duncan's multiple range test as modified by Kramer (1957) was used to make pair wise comparison among the least squares means with the use of inverse elements and root mean squares for error.

The correlation coefficients of various traits were computed according to the formula given by Rao (1985).

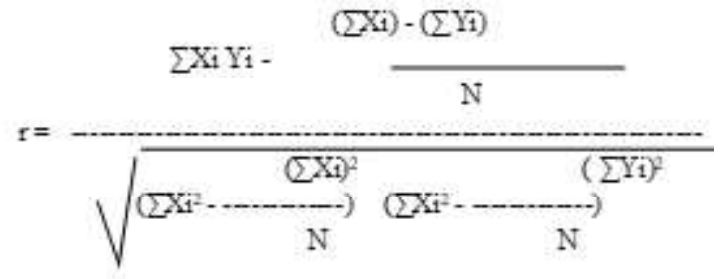

Where,

$$
\begin{aligned}
& \mathrm{Xi} \text { and } \mathrm{Yi} \text { are two variables } \\
& \mathrm{N}=\text { Total number of pair observations }
\end{aligned}
$$

The significance of correlation was tested by correlation table (Fisher and Yates, 1986).

\section{Results and Discussion}

\section{Biometry of Udder}

The overall least squares means of various udder parameters viz. udder length, udder width, udder depth and udder circumference of crossbred cows are presented in Table 2 .

The overall mean udder length in crossbred cows was $65.23 \pm$ $1.45 \mathrm{~cm}$. Effect of order of lactation on udder length was significant $(\mathrm{P}<0.01)$. Similar findings were reported by Mingoas et al. (2017) in Zebu cows. The udder length in cows of $6^{\text {th }}$ lactation onwards $(72.42 \pm 2.01 \mathrm{~cm})$ was significantly $(\mathrm{P}<0.05)$ higher than cows of $1^{\text {st }}(61.61 \pm 1.68 \mathrm{~cm})$ and $2^{\text {nd }}(63.38 \pm 2.38 \mathrm{~cm})$ lactation which did not differed significantly from each other. Increase in udder length with the advancement of lactation may be due to the physiological development of body and udder. Further decline in udder length may be due to shrinkage in udder with advancement of age. Influence of stage of lactation on udder length in crossbred cows was non-significant. Milk yield of cow increases during early stage of lactation and reaches peak at about 35-50 days and then declines gradually. With increase in milk yield, the udder length also increases. Hence, udder length may be higher during early stage of lactation.

The overall least squares mean of udder width in crossbred cows was $63.24 \pm 1.45 \mathrm{~cm}$. Similar udder width was noticed by Patel et al. (2016) in crossbred cows $(65.45 \pm 0.70 \mathrm{~cm})$. The difference due to parity in udder width was statistically significant $(\mathrm{P}<0.01)$. The udder width in cows of $6^{\text {th }}$ lactation onwards was significantly $(\mathrm{P}<0.01)$ higher than cows of $1^{\text {st }}$ to $5^{\text {th }}$ lactation, which did not differed significantly from each other. The effect of stage of lactation on udder width in crossbred cows was non-significant.

\begin{tabular}{|c|c|c|c|c|c|c|c|c|c|c|c|c|}
\hline \multirow{2}{*}{$\begin{array}{l}\text { Traits } \\
\text { of variation }\end{array}$} & & \multicolumn{3}{|c|}{ Udder length } & \multicolumn{3}{|c|}{ Udder width } & \multicolumn{3}{|c|}{ Udder depth } & \multicolumn{2}{|c|}{$\begin{array}{l}\text { Udder } \\
\text { circumference }\end{array}$} \\
\hline & d.f. & MSS & $\mathrm{F}$ & d.f. & MSS & $\bar{F}$ & d.f. & MSS & $\bar{F}$ & $\begin{array}{l}\text { d.f. } \\
\text {. }\end{array}$ & MSS & $\bar{F}$ \\
\hline OL & 5 & 324.46 & $3.13 *$ & 5 & 991.49 & $5.09^{* *}$ & 5 & 57.15 & 2.25 & 5 & 766.76 & $3.48 * *$ \\
\hline SL & 2 & 76.20 & 0.73 & 2 & 3.06 & 0.02 & 2 & 52.01 & 2.05 & 2 & 111.61 & 0.51 \\
\hline Error & 102 & 103.64 & & 102 & 194.68 & & 102 & 25.37 & & 102 & 220.37 & \\
\hline
\end{tabular}

Table 1 Least squares analysis of variance indicating effect of order of lactation and stage of lactation on udder measurement traits

\footnotetext{
* $\mathrm{P}<0.05 \quad * * \mathrm{P}<0.01$
} 
The mean udder depth recorded in crossbred cows was $19.03 \pm$ $0.51 \mathrm{~cm}$. The effect of order and stage of lactation on udder depth in crossbred cows was non-significant.

The differences observed in udder circumference in different lactations were statistically significant $(\mathrm{P}<0.01)$. Perusal of data showed a gradual increase in circumference of the udder as the lactations increased up to $3^{\text {rd }}$ which declined in $4^{\text {th }}$ lactation and then again increased during $5^{\text {th }}$ lactation onwards.

\section{Associations among udder biometry traits}

The udder length had positive and significant $(\mathrm{P}<0.01)$ correlations with udder width $(0.78)$, udder circumference $(0.58)$ and udder depth $(0.58)$ in crossbred cows. The correlations of udder width with udder circumference (0.71) and udder depth (0.70) were positive and significant $(\mathrm{P}<0.01)$. Also the positive and significant $(\mathrm{P}<0.01)$ correlations of udder circumference with udder depth $(0.52)$ was observed. These results indicated that all the udder measurement traits are highly associated with each other.

\section{Udder morphological characteristics}

A visual appraisal was made to record the shape of udder. Perusal of the data revealed that the frequencies of trough (bowl), round, goaty and pendulous type udder were $63.64 \%, 8.18 \%, 11.82 \%$ and $16.36 \%$, respectively. Thus, the trough type udder was observed in more than half of the cows. Present result was in agreement with Kamboj et al. (2007) who reported that trough shape udder was most frequent udder (45.94 \%) in Karan Fries cows.

\section{Various udder measurements in crossbred cows according to the udder shape}

Table 2 Udder measurements of crossbred cows in different order of lactation and stages of lactation

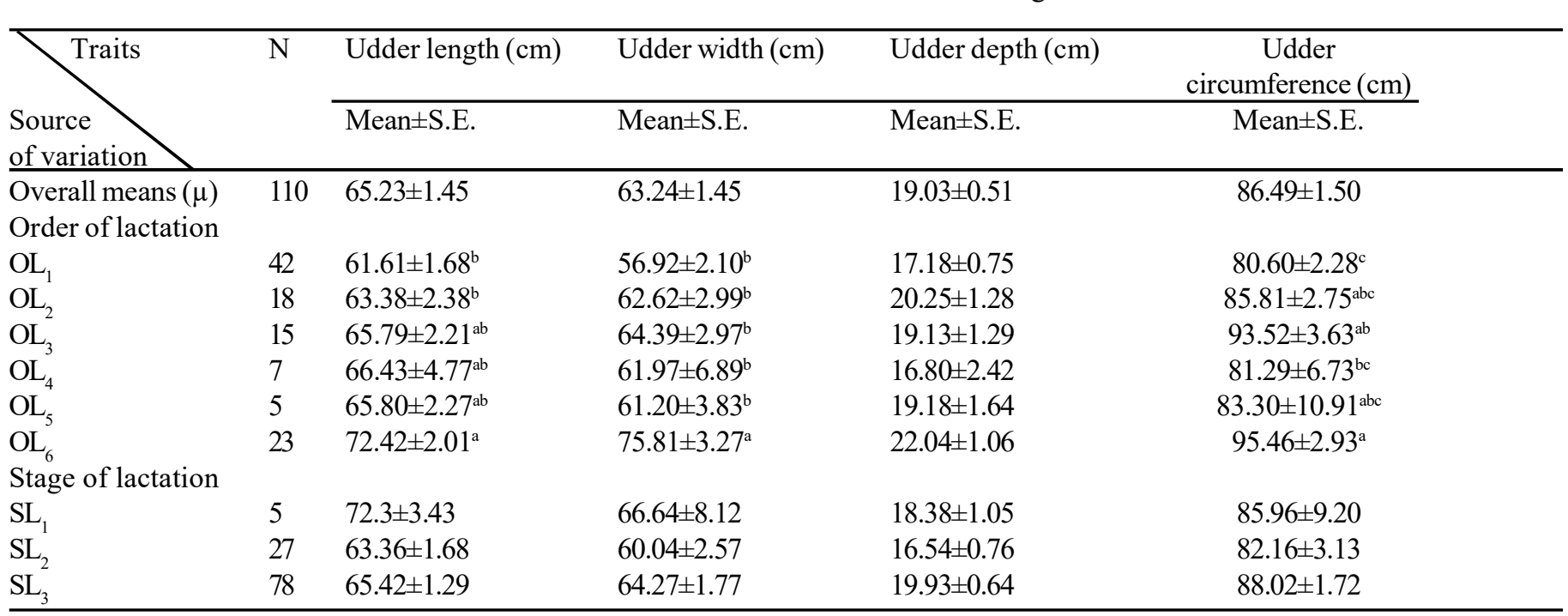

Means under each class in the same column with different superscripts differ significantly $(\mathrm{P}<0.05$ and $\mathrm{P}<0.01)$ from each other
The mean udder length in crossbred cows ranged from $61.23 \pm$ $1.20 \mathrm{~cm}$ in trough udders to $74.91 \pm 1.86 \mathrm{~cm}$ in pendulous udder, udder width ranged from $56.65 \pm 1.43 \mathrm{~cm}$ in trough udder to 77.40 $\pm 3.40 \mathrm{~cm}$ in pendulous udder. The udder depth ranged from $17.12 \pm 0.54 \mathrm{~cm}$ in trough udder to $23.96 \pm 1.24 \mathrm{~cm}$ in goaty udder. The udder circumference ranged from $80.93 \pm 1.78 \mathrm{~cm}$ in trough udder to $103.06 \pm 1.75 \mathrm{~cm}$ in round udder. The differences observed in mean udder length, width, depth and circumference due to different shape of udder were statistically significant $(\mathrm{P}<0.01)$.

Overall mean udder length, width, depth and circumference in crossbred cows were $65.23 \pm 1.45 \mathrm{~cm}, 63.24 \pm 1.45 \mathrm{~cm}, 19.03 \pm 0.51$ $\mathrm{cm}$ and $86.49 \pm 1.50 \mathrm{~cm}$, respectively. It was noticed that all udder dimensions were highest in pendulous udder followed by round, trough (bowl) and goaty udder. The udder shape had significant $(\mathrm{P}<0.01)$ effect on udder length, udder width, udder depth and circumference. The udder length, udder width and udder depth of cows having pendulous, goaty and round udder was significantly $(\mathrm{P}<0.01)$ higher than udder length, udder width and udder depth of cows having trough shape udder. The udder circumference of cows having round shape udder was significantly $(\mathrm{P}<0.01)$ higher than udder circumference of cows having goaty and trough shape udder. The udder circumference of cows having round shape udder was at par with udder circumference of cows having pendulous udder.

\section{Relationship between udder morphology and incidence of subclinical mastitis}

Prevalence of subclinical mastitis in cows with different shape of udder showed higher occurrence of subclinical mastitis in pendulous udder $(66.66 \%)$ followed by goaty $(53.84 \%)$, round $(44.44 \%)$ and trough (35.71\%) shape udder (Table 3$)$. The cows having pendulous udder had highest incidence of subclinical mastitis. This may be due to less distance between floor of udder 
and barn floor which increases the chance of entry of microorganisms. Similarly, long and pendulous udders have more chances of injuries due to weak suspensory ligament which helps the pathogens to grow. Uzmay et al. (2003) reported that Holstein cows with pendulous udder had the highest risk ofsubclinical mastitis. Thus, selection of cows against pendulous shaped udder could help in reducing the incidence of subclinical mastitis in crossbred cows. Bharti et al. (2015) observed that the mean SCC level for pendulous udder was significantly $(\mathrm{P}<0.05)$ higher as compared to the regular shaped udder. Sharma et al. (2017) noticed that milk SCC was found to be significantly $(\mathrm{P}<0.01)$ higher in pendulous type udder and lower in bowl shaped udder in crossbred cows. Prevalence of subclinical mastitis in trough shaped udder was observed to be $35.71 \%$. Hussain et al. (2012) reported $35.24 \%$ positive cases of SCM cows with trough shape udder which was in agreement with the present study.

\section{Relationship between udder biometry and incidence of} subclinical mastitis

The percentage of positive subclinical mastitis cases were found in cows with large udder length, udder width, udder depth and udder circumference category $(61.11 \%, 52.17 \%, 52.94 \%$ and $47.22 \%$ ). The large udder had more incidence of subclinical mastitis which may be due to the reason that large udder normally have wider area in contact with barn floor and had more chances of injury than the small udder. Further, when the cows are at rest, such udders gets spreads on the floor and gets contaminated which may be the possible cause for higher occurrence of subclinical mastitis.Udder depth had significant correlation with the mastitis. Higher the udder depth, lesser will be the distance of udder from floor making it vulnerable for risk of infection. In the present study, highest incidence (52.94\%) of subclinical mastitis was found in cows with udder depth greater than $25 \mathrm{~cm}$. Wattiaux (2005) reported that cows with too deep udder were more prone to mastitis or physical injuries.

\section{Relationship between order of lactation and incidence of subclinical mastitis}

The maximum occurrence (78.26\%) of subclinical mastitis was in sixth and above parity cows. This may be due to the reason that older cows were milked more and thus exposed more to environmental pathogens that causes subclinical illness and more likely to have damaged teats or udder tissue in which contagious infection can easily enter and colonize. George et al. (2007) reported increased occurrence of subclinical mastitis with advancement of parity in crossbred cows.

\section{Relationship between stages of lactation and incidence of subclinical mastitis}

The highest occurrence of subclinical mastitis in crossbred cows was observed in late stage of lactation $(46.15 \%)$ followed by early $(40 \%)$ and $\operatorname{mid}(37 \%)$ stage of lactation. Higher prevalence
Table 3. Incidence of subclinical mastitis in cows with different shape of udder

\begin{tabular}{llll}
\hline $\begin{array}{l}\text { Udder } \\
\text { shape }\end{array}$ & Frequency & $\begin{array}{l}\text { Incidence } \\
\text { of SCM }\end{array}$ & Percentage \\
\hline Pendulous & 18 & 12 & 66.66 \\
Goaty & 13 & 7 & 53.84 \\
Round & 9 & 4 & 44.44 \\
Trough & 70 & 25 & 35.71 \\
Overall & 110 & 48 & 43.64 \\
\hline
\end{tabular}

Table 4. Udder biometry and incidence of subclinical mastitis

\begin{tabular}{lllc}
\hline $\begin{array}{l}\text { Parameter } \\
\text { Udder length }(\mathrm{cm})\end{array}$ & $\begin{array}{l}\text { No. of } \\
\text { cows }\end{array}$ & $\begin{array}{l}\text { Positive } \\
\text { for SCM }\end{array}$ & Percentage \\
\hline$<55$ & 18 & 5 & 27.77 \\
$55-75$ & 74 & 32 & 43.24 \\
$>75$ & 18 & 11 & 61.11 \\
Udder width $(\mathrm{cm})$ & & & \\
$<55$ & 33 & 11 & 33.33 \\
$55-75$ & 54 & 25 & 46.3 \\
$>75$ & 23 & 12 & 52.17 \\
Udder depth $(\mathrm{cm})$ & & & \\
$<15$ & 26 & 9 & 34.61 \\
$15-25$ & 67 & 30 & 44.78 \\
$>25$ & 17 & 9 & 52.94 \\
Udder circumference & $(\mathrm{cm})$ & & \\
$<75$ & 28 & 12 & 42.86 \\
$75-95$ & 46 & 19 & 41.3 \\
$>95$ & 36 & 17 & 47.22 \\
\hline
\end{tabular}

Table 5. Correlations of udder measurement traits with incidence of subclinical mastitis

\begin{tabular}{lc}
\hline Traits & Incidence of subclinical mastitis \\
\hline Udder shape & $0.24^{*}$ \\
Udder length & $0.19^{*}$ \\
Udder width & 0.16 \\
Udder circumference & 0.01 \\
Udder floor to ground & $-0.19^{*}$ \\
Udder depth & $0.27^{* *}$ \\
Lactation order & $0.37^{* *}$ \\
Stage of lactation & 0.01 \\
\hline
\end{tabular}
${ }^{*} \mathrm{p}<0.05{ }^{* *} \mathrm{p}<0.01$

of mastitis in late stage of lactation may be due to removal of protective keratin plug in teats. Tancin (2013) in dairy cows reported higher occurrences of subclinical mastitis in early and late lactation. Syridion et al. (2013) also reported higher incidence of SCM during late stage of lactation in Holstein Friesian crossbred cows.

\section{Correlations of uddermeasurement traits with incidence of} subclinical mastitis 
The correlation coefficient of udder shape (0.24) with incidence of subclinical mastitis was positive and significant $(\mathrm{P}<0.05)$. Similar results were reported by Bharati et al. (2015) in crossbred cows. The results showed that with increase in udder length, there was increase in incidence of subclinical mastitis. The udder width $(0.16)$ and udder circumference $(0.01)$ had positive and non-significant association with incidence of subclinical mastitis. The correlation of udder depth (0.27) with incidence of subclinical mastitis was positive and significant $(\mathrm{P}<0.01)$. The results showed that lesser the udder depth, higher the cases of incidence of subclinical mastitis. This result was in line with the findings of Nemcova et al. (2007) in Holstein cows. The distance between udder floor to ground (-0.19) had negative and significant $(\mathrm{P}<0.05)$ correlation with incidence of subclinical mastitis. The results indicated that lesser the distance between udder floor to ground, higher the cases of subclinical mastitis.

\section{Conclusions}

The frequencies of trough (bowl), round, goaty and pendulous type udder in crossbred cows were $63.64 \%, 8.18 \%, 11.82 \%$ and $16.36 \%$, respectively. Traits like udder shape, udder length and udder depth had positive and significant association with incidence of subclinical mastitis. Stages of lactation and higher lactation order were associated with increased incidence of subclinical mastitis.

\section{Acknowledgement}

The authors extend their sincere thanks to MPKV, Rahuri for providing the facilities for conducting the present investigation.

\section{References}

Bharti P, Bhakat C, Pankaj PK, Bhat SA, Prakash MA, Thul MR and Japeth KP (2015) Relationship of udder and teat conformation with intra-mammary infection in crossbred cows under hot-humid climate. Vet World 8: 93-98

Cerkascenko I (1958) Mol Mjasn Zivotn. Anim Breed. Abstr. 3:36

Fisher RA and Yates F (1986) Statistical table for biological, agricultural and medical research. Sixth Edn. Publishers Longman group Ltd England Pp, 63

George S, Joshi HC, Suman CL, Rathore RS and Bisht GS (2007) Incidence of subclinical mastitis in crossbred cattle herd. Indian J Anim Prod Manage 23: 1-4
Harvey WR (1990) Least squares analysis of data with unequal subclass number. USDA, ARS. 144

Hussain R, Khan A, Tariq JM. And Rizvi F (2012) Possible factors associated with mastitis in Indigenous cattle in Punjab, Pakistan. Pakistan Vet J 32: 605-608

Kamboj ML, Anshaj Singh and Shiv Prasad (2007) Effect of udder and teat shapes and their measurements on somatic cell counts in milk of Karan-Fries cows. Indian J Dairy Sci 60: 435-440

Kramer CV (1957) Extension of multiple range tests to group correlated adjusted means. Biometrics 13: 13-18

Mingoas KJP, Awah-Ndukum J, Dakyang H and Zoli PA (2017) Effects of body conformation and udder morphology on milk yield of zebu cows in North region of Cameroon Vet World 10: 901

Nemcova E, Stipkova M, Zavadilova L,Bouska J and Vacek M (2007) The relationship between somatic cell count, milk production and six linearly scored type traits in Holstein cows. Czech J Anim Sci 52: 437- 446

Patel YG, Trivedi MM, Rajpura RM, Savaliya FP, and Parmar M (2016) Udder and teat measurements and their relation with milk production in crossbred cows. Int J Sci Environ Technol 5: 3048-3054

Pyorala S (2003) Indicators of inflammation in the diagnosis of mastitis. Vet Res 34: 565-578

Rao GN (1985) Statistics for Agricultural Sciences Oxford and IBH Publishing Co New Delhi pp. 376

Sharma T, Das PK, Ghosh PR, Banerjee D and Mukherjee J (2017) Association between udder morphology and in vitro activity of milk leukocytes in high yielding crossbred cows. Vet World 10: 1-6

Syridion D, Layek SS, Mohanty TK, Kumaresan A, De, Kalyan, Manimaran A, Prasad Shiv and Venkatasubramanian V (2013) Effect of production systems on milk quality parameters in Holstein Friesian crossbred cows. Indian J Dairy Sci 66: 424-431

Tancin V (2013) Somatic cell counts in milk of dairy cows under practical condition. Slovak J Anim Sci 46: 31-34

Uzmay C, Kaya Y, Abbas Y and Kaya A (2003) Effect of udder and teat morphology, parity and lactation stage on sub-clinical mastitis on Holstein cows. Turk. J Vet Anim Sci 27: 695-710

Wattiaux MA (2005) Reproduction and genetic selection goals. Babcock Instt Int Dairy Res Dev 17: 1-6

Zdunczyk S, Zerbe H and Hoedemaker M (2003) Importance of oestrogen and oestrogen-active compounds for udder health in cattle: A review. Dtsch Tierarztl Wochenschr 110: 461 